\title{
Remarks on the Integration of Special Collections
}

\section{Clifton H. Jones}

Increasingly stringent budgets, library automation, and the anticipated imposition of the USMARC format for both print and non-print materials have encouraged special collections repositories to reevaluate their roles within libraries. During the past several decades, rare book librarians, archivists, and manuscript and other special collections curators have developed their own acquisition, processing, cataloging, and access standards for their collections. Gradually, libraries have accepted the necessity for separate procedures. However, while the unique needs of users of special collections are better served, the special collections repository, as a result of its independence, has been isolated from the mainstream of library development. Also, individual collections within the repository are often isolated from one another. This paper offers a brief history of the development of separate standards for archives, rare book, and manuscript collections; a description of the impact of these standards on the administration of repositories; and a discussion of the prospects for the integration of collections within the repository itself and of the repository within the mainstream of libraries.

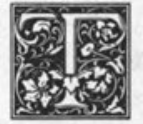

he integration of component collections within special collections libraries is certainly not a new question. In fact it was not too many years ago that more than a few libraries cataloged manuscripts following much the same standards as they did for their books. However effective that particular form of integration may or may not have been, the issue-perhaps specter to some-of integration is again reappearing, prompted by two primary factors.

The development of new bibliographic standards alone raises the question of compatible cataloging formats, not only for the various forms of printed materials, but also for such special collections materials as three-dimensional artifacts, graphic materials, manuscripts, and possibly even archival collections. The soon-to-be issued Library of Congress interpretation of AACR2's chapter on manuscripts, for example, accepts USMARC for manuscripts, while at the same time stressing the importance of the finding aid; OCLC has addressed the question of standard format for manuscripts in the use of its data base; and RLIN, at a project at Yale, is addressing the same question for its own system. These efforts all represent a form of integration, because once a record of a manuscript or special collections' holding is entered into the common data base, it is integrated with all other records already there. If an acceptable machine-readable format for manuscripts appears, conceivably one can be devised for other nonprint materials as well.

The full effect of bibliographic standards in automation won't be felt until sometime in the future. Today, perhaps the prime motivation for integration of special collections is financial. With shrinking budgets in libraries, it is becoming increasingly difficult to justify traditional approaches in the administration of special collections. It is ironic that it is by no means unusual for an administration to authorize an expenditure of several thousand dollars for a rare imprint, only to balk

Clifton H. Jones is director of the DeGolyer Library, Southern Methodist University, Dallas, Texas 75275. This paper was presented at the Rare Books and Manuscripts Section general program meeting at the 1983 ALA Annual Conference in Los Angeles. 
at the high cost of processing a gift collection of several hundred titles which that same administration may have accepted as a favor for a donor seeking a tax deduction. Frustrating, perhaps, but the lack of support is a fact of life. The labor costs of special collections are high in acquisition, cataloging, promotion and development, and public services. While we may argue that virtually all of our programs are underfunded, special collections, like any other program in a library, must justify its existence through its productivity. Its productivity will ultimately be measured, I feel, on the basis of its use, although the value of the status and prestige that it lends to its parent institution will remain a factor.

Special collections, like all other library programs, will be under increasing pressure to justify their operations. For illustration, it is not that unusual, even today, for special collections to acquire a manuscript collection in a field without considering whether their other collections, much less the general library, can properly support that acquisition with complimentary primary and secondary source material. Such acquisitions will have, at best, restricted research value. Special collections will, as a consequence of budget cutbacks, find themselves under pressure to write collection development policies in order to define acquisition fields for all of their collections. The right hand within special collections will, perhaps for the first time, know what the left hand is doing. It will become increasingly costly for special collections to compete effectively for the budget dollar if its own voice is divided into several competing collections. In short, the budget crisis will force special collections both to justify its operations and to compete more effectively for financial support.

The forces of automation, bibliographic standardization, and budget cutbacks raise the question of integration. Even if we accept the definition of integration as the adoption of certain common bibliographic and administrative standards and processes for the various holdings in special collections, that does not justify integration, if indeed it can be justified. Joyce and Berner will be arguing their cases for and against integration. My task is to describe and analyze the various factors that have so far encouraged the separation of archives, manuscript, and rare book collections-three of the more important collections found in special collectionsand to comment briefly on future prospects of integration.

Special collections programs have not yet achieved integration due to a series of interrelated factors. It is partly a question of the history of the field and the diversity of the formats of holdings found in special collections. Many special collections originated in the donation of a private gift to a library which may have included not only books, but also such materials as personal papers, memorabilia, and photographs. Admittedly, a library often accepted material more for the status and prestige that the gift conferred than for its potential research value. As additional gifts were accepted, the body of disparate materials grew large enough that the library could establish a special collections unit. I have not come upon a better working definition of special collections than a repository for all those collections that a library does not know what else to do with. The result has been that a special collections repository typically holds a considerable diversity of materials.

Gradually, libraries have accepted the need for differing acquisition, processing, and accessing methods for the different collections commonly found in special collections. By accepting different management methods for rare books, archives, and manuscripts, libraries may have insured that the integrity of each format is respected, but the approach also encourages the independent administration of each collection.

With the acceptance of separate management procedures for the major formats in special collections has come the increasing appreciation for the need for appropriately trained staff. The M.L.S. remains significant, of course, but the field of archives in particular, has established its own standards in education and training.

Archivists can trace the origins of their profession to at least as early as the French 
Revolution, but it was not until the 1930 s that the profession gained impetus in this country with the establishment of the $\mathrm{Na}$ tional Archives and subsequently, the organization of the Society of American Archivists. The SAA, while it has not yet established formal educational standards or accreditation procedures for training programs, nonetheless has led a very effective effort in education through its publication program, its workshops and seminars, and its active conference schedule. As a result, general libraries have come to accept, if ever so slowly, the special administration of an archives-that an archives is to be administered by archival conventions, not by standard library procedures.

The history of the rare book profession is considerably different. Allied much more closely with general librarianship than archives, this profession reflects the history of the rare book collection. Since many collections were originally established on the basis of their aesthetic value, it should not be surprising that the rare book librarian is often more concerned with a title's rarity than with its research value. Actually, that perception of the rare book librarian may be based more on stereotype than reality. Today, most rare book librarians readily acknowledge the potential research value of their collections; the problem is often convincing others outside the rare book collection of such potential. There remains a strong tradition of the scholar-bibliographer in rare books, but the M.L.S. has become the required credential. Rare book description differs greatly from archives, of course, although it does stress provenance. Generally, rare book description accepts standard cataloging rules, while placing greater stress upon certain USMARC fields.

The educational and professional differences between those working with archives on the one hand and rare books on the other represent the extremes in the range of educational traditions in special collections. At least one other group of professionals, however, has distinguished itself in recent years.

Manuscripts curators are neither wholly archivist in their outlook nor librarian.
Some are trained as archivists, some have an M.L.S., a few are trained in both areas. The field has not yet developed its own educational or training standards, but the collections that manuscript curators control have dictated the development of procedures specific to the needs of manuscript collections. While a few manuscript collections continue to catalog manuscripts on an item-by-item basis (a procedure which may have some justification in a literary collection), many other repositories have adopted, at least in part, general archival principles. Most libraries today do accept that manuscripts are not to be managed as printed items, which are, by and large, collections of personal papers, but nonetheless differ from the management of an institutional archives. In administering their collections, manuscript curators have adopted methods and ideas from both libraries and archives, and with good results, I believe. The finding aid, an archival tool, has been used to great advantage, but since access through provenance is, by itself, of limited effectiveness, many manuscript curators have borrowed the idea of subject access from libraries and use entries in a card catalog to index their finding aids.

Not only do educational and processing standards differ, but so does the use of rare books, archives, and manuscripts. Research use of most rare book collections is seldom high; the great majority of research requests in college and university archives are administrative in nature; but almost all requests in manuscripts relate to historical or related research. The type of use in all these areas, however, may be changing.

Differences in professional standards, conventions, and education have been exacerbated by a major shift that has occurred in many special collections repositories. Certainly, a few special collections libraries retain the proud tradition of the rare title or manuscript. Other special collections, however, are changing, if they have not already done so, to collections that emphasize specific subjects. This shift involves the challenging conversion of collections from being defined loosely (e.g., by the acceptance of all-too-often 
unrelated gifts) to collections defined by formal collection development policies. The result is that once a library defines its acquisition program, a special collections program has the opportunity to acquire materials in the areas of its greatest strength. As the subject strengths of collections have thus become evident, research use increases. Increasing research use will encourage further changes in the administration of these special collections repositories, thereby separating them from the more traditional programs.

As such, the emergence of subjectoriented special collections has signaled a major shift in the character of special collections. I repeat that rare items and fine bindings continue to hold a very respectable position in the traditions of special collections; but just the same, the research value of the holdings in special collections is-if ever so slowly-becoming recognized, even outside of the field of special collections itself. Such outside recognition is critical if support for special collections is to improve. Above all, special collections represent a repository of primary source research materials. However strong a general library's research collection may be, it cannot effectively support research in history and related fields without comparably strong special collections. The research value of archives, manuscripts, and subject collections is selfevident (at least it is, once the collections are processed and accessible), but the aesthetic reputation of rare books should not obscure their potential research value either. Thus, while the shift to subject emphasis in many special collections may indeed have encouraged the further separation of archives, rare books, and manuscripts, the emergence of subjectoriented collections has also raised the possibility of greater support for the programs due to greater use of the collections.

I mentioned earlier that the pressures of automation and the resulting pressure for common bibliographic standards, and budget justification are among the forces pressuring for integration in special collections. To raise the issue of integration is not to justify that process, but simply to recognize what may occur as a result of these forces. In my own view, the possibility of providing better access to holdings provides the one good reason for integration. Budget justification may be a good motivation, but it alone is not a sufficient reason for integration. If a library's special collections' prime value to an institution is its prestige, as is often the case, integration loses its importance. On the other hand, in a research-oriented collection, integration offers the prospect of insuring, for example, that a scholar examining manuscripts will also be directed to materials of value in the program's subject collections, its archives, rare books, and, for that matter, to holdings in other libraries once the holdings of special collections are entered into the common database of a bibliographic utility. However, if integration offers the promise of more effective access, it also offers dangers.

It must be remembered that the separation of archives, rare books, and manuscripts is the result of necessity. In the case of the rare book, it has been possible to rely on the standards of the AngloAmerican Cataloging Rules, but both archivists and manuscript curators have been forced to develop their own procedures to insure the integrity of their holdings. It is not a question of one set of traditions or standards being right and the others wrong; rather it is simply that the essential, basic conventions of each field must be respected if all the holdings in special collections are to be managed effectively. If rare book librarians, manuscript curators, and archivists are to accept integration, they must be assured that those principles they feel to be essential to the management of their particular collections are not being challenged heedlessly.

The appearance of bibliographic standards and pressures upon budgets may have raised the issue of integration; the individual traditions and conventions of archives, manuscripts, and rare books may have led to their separation; and the emergence of the research-oriented special collections may have cemented that separation, but, nonetheless, I wonder if the prime force, which will determine if inte- 
gration is to be achieved or forgotten, is not far more elementary in its nature than any of these factors.

Special collection programs and those individuals who work within special collections enjoy an independence, not only in respect to the management of their own individual collections, but also in the larger sphere of the parent institution. The status and prestige of the collections, the mystique of the fields involved, and the specialized skills that archivists, manuscript curators, and rare book librarians have acquired have insulated special collections from the scrutiny that is common to all other programs in a library-few library administrators know enough about work in special collections to judge its effectiveness. As such, the issue of integration concerns not only the administration of separate collections within special collections, but also the role of special collections within the general repository.

Undoubtedly, archivists, rare book librarians, and manuscript curators appreciate their independence. If integration threatens that independence, what is likely to be their reaction? I suspect that few individuals would willingly give it up, at least not without a fight.

A second way to perceive this independence is to view it as isolation. A library administrator may respect the indepen- dence of an archives, for example, but that archives may be facing a very uncertain future if, in its isolation, the archives is forgotten at each budget cycle. This afternoon, our panel will raise the question of integration and discuss its pros and cons in respect to collections within special collections. Perhaps an even more important question, considering the competition for the budget dollar, is the integration of special collections within the mainstream of libraries. The prospect of integration at either level is not good.

I fear that the chief obstacle to integration will probably not be the objections involving bibliographic standards or education, but will be the desire of many to protect the often very personal bailiwicks that so many collections within special collections have become, and the desire to protect the status that so many professionals associate with their collections and with their own particular specialities, even at the great cost of isolation.

If the essential conventions and standards of rare books, archives, and manuscripts can be protected, integration may certainly represent a viable alternative to the traditional administration of special collections. It is regrettable that its future is likely to be determined by the desire to protect empires and by questions of status. 